\title{
Hypothalamohypophyseal Portal System
}

National Cancer Institute

\section{Source}

National Cancer Institute. Hypothalamohypophyseal Portal System. NCI Thesaurus. Code C32759.

A system of vessels between the hypothalamus and anterior pituitary in which blood, after passing through one capillary bed, is conveyed through a second set of capillaries before it returns to the systemic circulation. 